\title{
Modifikasi Skema Teknik Tanam Padi dan Bajak Sawah Berbasis Square Transposition 64-bit
}

\author{
http://dx.doi.org/10.28932/jutisi.v7i1.2973 \\ Riwayat Artikel \\ Received: 23 September 2020 | Final Revision: 15 Maret 2021 | Accepted: 24 Maret 2021
}

\author{
Nadya Glorya Najoan ${ }^{\bowtie \# 1}$, Magdalena Ariance Ineke Pakereng ${ }^{* 2}$ \\ \# Jurusan Teknik Informatika, Universitas Kristen Satya Wacana \\ Jl. Dr. O. Notohamidjojo, Kel. Blotongan, Kec. Sidorejo, Salatiga \\ ${ }^{1}$ najoannadya25egmail.com \\ * Jurusan Teknik Informatika, Universitas Kristen Satya Wacana \\ Jl. Dr. O. Notohamidjojo, Kel. Blotongan, Kec. Sidorejo, Salatiga \\ ${ }^{2}$ ineke.pakereng@uksw . edu
}

\begin{abstract}
Cryptography is a study discussing mathematic technics that related to information security aspects such as secrecy, data integrity, and authenticity. This research discusses how to modify a scheme while looking for random points using different pickup points and income points. While looking for the random point in the modified scheme research using the rice planting and field plow techniques, it has three testing processes which were runtest, monobit, and blockbit tests. This research used square transpositions 64-bit with the size $8 \times 8$ and it got a high result with p-value $7.3239 \times 10^{-10}$, pvalue monobit 1.00000000 and $p$-value blockbit 1 that showed non-random result with the smallest $p$-value was 0.011662392 with p-value monobit 1.00000000 and the $p$-value blockbit 0.99990476 that made this research got a random result.
\end{abstract}

Keywords - Blockbit; Cryptography; Monobit; Runtest; Square Transposition.

\section{Pendahuluan}

Pada zaman modern seperti sekarang ini, perkembangan teknologi dan informasi sangat dibutuhkan oleh banyak orang. Hadirnya teknologi dan informasi, menyebabkan orang-orang bisa saling berkomunikasi walaupun dengan jarak yang sangat berjauhan. Internet merupakan salah satu hal yang bisa menghubungkan seseorang untuk berkomunikasi dan saling bertukar informasi dengan orang yang lain walaupun berada pada tempat yang berbeda. Beberapa orang ingin memberikan informasi untuk diberikan kepada pihak yang ditujunya dengan rahasia atau tanpa diketahui oleh orang lain. Berbagai carapun dilakukan supaya informasi yang akan diberikan tidak diketahui oleh pihak tidak berwenang sebelum sampai kepada pihak terkait. Maka dari itu kriptografi hadir untuk membantu mengamankan informasi dan data yang ada.
Kriptografi yang baik memiliki pola yang acak dan beragam[1], pola acak penting dalam kriptogtafi karena untuk menjadikan nilai tidak dapat diprediksi atau unpredictable[2], sehingga penelitian ini dirancang dengan menggunakan algoritma yang diterapkan dalam kriptografi yaitu algoritma block cipher 64-bit berbasis pada teknik tanam padi dan bajak sawah yang sudah diteliti sebelumnya[1], kemudian akan dimutasi nilai keacakannya pada tiga pengujian yaitu runtest, monobit dan blockbit.

Kendala yang ada pada penelitian sebelumnya telah diuji dengan menggunakan pola pengambilan dan pemasukan tanam padi dan bajak sawah dengan hasil yang didapatkan bernilai tidak acak, sehingga dilakukannya pengujian kembali dengan memodifikasi atau memperbaiki pola pengambilan dan pemasukan dari tanam padi dan bajak sawah sehingga memperoleh hasil yang bernilai acak.

Berdasarkan latar belakang yang ada maka dilakukan pengujian kembali dengan memodifikasi skema teknik tanam padi dan bajak sawah berbasis square transposition 64-bit sebagai pemenuhan nilai keacakan dari penelitian sebelumnya.

\section{TINJAUAN PUSTAKA}

Kriptografi sendiri adalah ilmu yang mempelajari teknikteknik matematika yang berhubungan dengan aspek keamanan informasi seperti kerahasiaan, integritas data serta otentikasi [3]. Kriptografi ini merupakan sebuah metode untuk mengamankan data maupun informasi dalam bentuk sandi sehingga tidak dapat dimengerti maknanya lagi. Melalui proses enkripsi dan dekripsi data atau pesan dapat diubah ke bentuk sandi dan memerlukan kunci untuk mengerti makna berdasarkan sandi tersebut. Namun bukan 
jaminan data atau pesan menjadi aman ketika sudah diterapkan algoritma kriptografi di dalamnya karena seiring kemajuan kriptografi semakin banyak pula oknum-oknum yang ingin memecahkan algoritma tersebut [4].

Perancangan kriptografi block cipher yang dilakukan sekarang ini memerlukan penelitian yang telah dilakukan sebelumnya sehingga dapat digunakan sebagai dasar atau pembanding dari penelitian ini. Penelitian yang berjudul Modifikasi Skema Teknik Tanam Padi dan Bajak Sawah Berbasis Square Transposition 64-bit sebagai Pemenuhan Nilai Keacakan adalah acuan dari penelitian ini dimana pada proses tanam padi dilakukan proses menaruh bibit padi pada sebidang tanah yang membentuk aturan pola tertentu agar dapat tumbuh dengan baik. Proses tanam padi ini membentuk alur horizontal dan vertikal yang saling berkesinambungan. Proses dalam menaruh bibit padi dengan memasukkan bibit padi sekitar $5 \mathrm{~cm}$ ke dalam tanah, setelah terisi mundur ke belakang sesuai petakan sawah. Sedangkan Proses bajak sawah sendiri adalah mengerjakan tanah dengan menggunakan alat yang disebut bajak. Tujuan dari membajak tersebut yaitu dengan membalikkan tanah yang sebelumnya ada di lapisan paling atas sudah ditumbuhi rumput dan cenderung lebih keras, maka dengan proses dibajak lapisan tanah di bawahnya naik ke atas dan menjadi lebih gembur. Proses bajak sawah menggunakan pola spiral dimulai dari titik terluar atau pinggur, setelah itu memutar mengelilingi titik pusat [1].

Run Test dapat digunakan untuk melihat apakah observasi (sampel) diambil secara acak atau tidak. Barisan yang dilakukan pengujian menggunakan run test dapat berupa uji biner maupun uji non-biner. Pada penelitian ini dilakukan strategi penerapan untuk melakukan uji keacakan barisan bit menggunakan run test [5]. Dalam pengujian ini mencari jumlah total lintasan dalam suatu rangkaian, dimana lintasan adalah rangkaian tak berujung dari bit yang identik. Tujuan dari percobaan lintasan ini untuk menentukan jumlah lintasan satu dan nol dalam berbagai jarak untuk suatu rangkaian yang acak. Secara khusus, percobaan ini menentukan apakah pergerakan antara nol dan satu terlalu cepat atau terlalu lambat Panjang lintasan $k$ terdiri dari bit $k$ yang identik dan dibatasi sebelum dan sesudah oleh suatu bit dengan nilai yang berlawanan, nilai berlawanan yang dimaksud jika value 0 atau 1 sudah di input sebelumnya maka nilai berlawanannya yang di input 1 atau 0. [6].

Monobit Test adalah pengujian untuk menentukan apakah jumlah satu dan nol dalam suatu rangkaian kurang lebih sama dengan yang akan diperkirakan terhadap suatu rangkaian yang benar-benar acak. Percobaan ini memperhitungkan pendekatan suatu fraksi atau pecahan dari satu sampai setengah, itulah jumlah dari satu dan nol dalam suatu rangkaian yang seharusnya sama [6].

Blockbit Test adalah percobaan untuk menentukan apakah frekuensi dari satu dalam suatu balok $M$-bit adalah kurang lebih $\mathrm{M} / 2$, sama seperti yang akan diharapkan dalam suatu perkiraan yang acak. Untuk balok berukuran $\mathrm{M}=1$, percobaan ini merosot kembali ke percobaan 1, yaitu percobaan Frekuensi Monobit[6].

Square Transposition merupakan salah satu jenis dari transposisi cipher. Square Transposition sendiri dapat digunakan dengan aman apabla kunci yang digunakan cukup panjang[7]. Square Transposition sendiri terdiri dari dua proses yaitu memasukka bit ke dalam square dan proses pengambilan bit dengan ukuran yang telah ditentukan sebelumnya[8].

Batik Bentenan merupakan kain batik traditional hasil karya Suku Minahasa yang ada sekitar abad ke-7 [9]. Motif Batik Bentenan yang digunakan pada penelitian ini adalah motif dari kain Tinompak yaitu motif yang berarti muncul atau memunculkan simbol-simbol selain simbol manusia (human figure), misalnya menambahkan motif pakis hutan (flora) dan motif ekor ikan (fauna)[10]. Motif Tinompak juga adalah salah satu teknik tenunan dengan aneka pola dengan gambar yang berulang[11].

Pengujian Nilai Keacakan dilakukan untuk melihat seberapa baik rancangan kriptografi mengacak nilai plaintext. Nilai keacakan sendiri dilihat dapat dilihat dari selisih perbandingan plaintext dengan cyphertext terhadap plaintext karena selisih pada pembilang, pada persamaan dengan kemungkinan yang muncul pada nilai keacakan dapat bernilai positif maupun negatif. Apabila mendapatkan nilai negatif berarti perbandingan nilai cyphertext lebih besar dari nilai plaintext begitu juga sebaliknya apabila mendapatkan nilai positif berarti nilai plaintext lebih besar dari nilai cyphertext [12].

\section{METODE PENELITIAN}

Tahapan penelitian ini terdiri dari 4 (empat) tahapan, yaitu: (1). Identifikasi masalah, (2). Tinjauan Pustaka, (3). Pengujian Nilai Keacakan dan Analisa (4). Penulisan Artikel Ilmiah

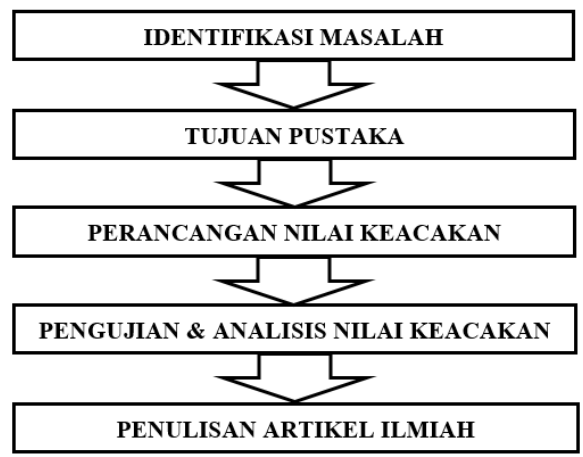

Gambar 1. Tahapan Penelitian

Tahapan penelitian pada Gambar 1 dapat dijelaskan sebagai berikut:

Tahap pertama: Identifikasi masalah merupakan tahap awal untuk mencari permasalahan dari nilai yang tidak acak 
menjadi acak atau dengan kata lain penelitian tentang Pseudo Random Number Generator dengan Modifikasi Skema Teknik Tanam Padi dan Bajak Sawah Berbasis Square Transposition 64-bit sebagai Pemenenuhan Nilai Keacakan yang berkaitan dengan Modifikasi Skema Teknik Tanam Padi dan Bajak Sawah Berbasis Square Transposition 64-bit sebagai Pemenenuhan Nilai Keacakan; Tahap kedua: Tinjauan pustaka dilakukan dengan mengumpulkan referensi dari buku, jurnal atau sumber lain yang berguna dalam perancangan kriptografi; Tahapan ketiga: Perancangan Nilai Keacakan pada Skema Teknik Tanam Padi dan Bajak Sawah Berbasis Square Transposition 64-bit sebagai Pemenuhan Nilai Keacakan; Tahapan keempat: Pengujian dan analisa Nilai Keacakan pada Modifikasi Skema Teknik Tanam Padi dan Bajak Sawah Berbasis Square Transposition 64-bit sebagai Pemenuhan Nilai Keacakan. Penulisan laporan dari hasil penelitian yang dilakukan mengenai proses Modifikasi Skema Teknik Tanam Padi dan Bajak Sawah Berbasis Square Transposition 64-bit sebagai Pemenuhan Nilai Keacakan.

Dalam memodifikasi skema teknik tanam padi dan bajak sawah berbasis square transposition dilakukan dua proses yaitu pola pengambilan dan pola pemasukan.
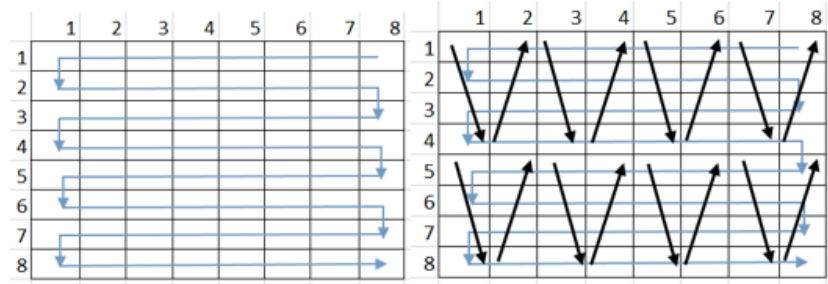

Gambar 2. Pola Pengambilan Zig-zag dan Pola Pemasukan Tanam Padi

Dalam pengujian ini adalah menggunakan pola pengambilan zig-zag dan pemasukan menggunakan pola tanam padi yang dibagi menjadi dua bagian yaitu bagian atas dan bagian bawah. Setelah itu pemasukan dimulai dari bagian atas samping kiri mengikuti arah panah ke bagian bawah empat karakter dan ke kanan satu karakter setelah itu naik ke bagian atas tiga karakter mengikuti arah panah dilakukan dengan cara yang sama untuk bagian bawah seperti pada Gambar 2 [4].
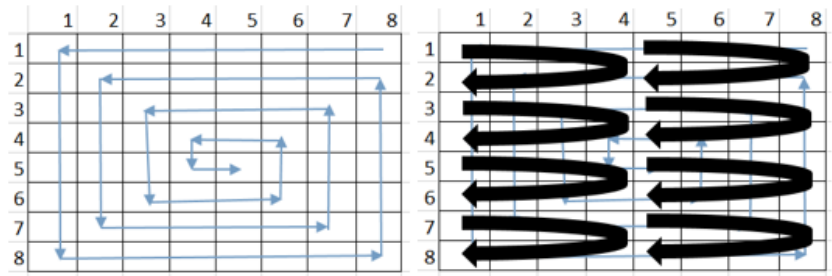

Gambar 3. Pola Pengambilan Spiral dan Pola Pemasukan Bajak Sawah
Dalam pengujian menggunakan pola pengambilan spiral dan pola pemasukan bajak sawah dimulai dari pengambilan dari samping kanan atas dan pemasukan dari samping kiri atas maju ke kanan 4 karakter kemudian berurutan ke bawah ke kiri empat karakter mengikuti arah anak panah pada Gambar 3 [4].

\section{HASIL DAN PEMBAHASAN}

Dalam bagian ini akan membahas mengenai Modifikasi Skema Teknik Tanam Padi dan Bajak Sawah Berbasis Square Transposition 64-bit sebagai Pemenuhan Nilai Keacakan secara terinci.

Proses pertama dalam mencari nilai keacakan dengan menggunakan pola pengambilan spiral dan pemasukan bajak sawah mendapatkan hasil yang acak seperti pada Gambar 4.

\begin{tabular}{|c|c|c|c|c|c|c|c|}
\hline \multicolumn{8}{|c|}{ Pola Pemasukan 6} \\
\hline 8 & 7 & $\Delta-5$ & $\rightarrow 5$ & $1-1$ & $\Rightarrow$ & $1-2$ & $\rightarrow$ \\
\hline & 34 & 334 & 32 & 31 & $\times 30$ & 29 & $\checkmark$ \\
\hline 110 & $\Rightarrow \beta 5$ & $\begin{array}{r}52 \\
\end{array}$ & 51 & 50 & $\rightarrow \quad 49$ & $1 \times 4$ & 27 \\
\hline 11 & 36 & 53 & 62 & 61 & 60 & 47 & 26 \\
\hline 12 & $\longrightarrow 37$ & 154 & $\rightarrow 63$ & 54 & 59 & 4.6 & $\Rightarrow$ \\
\hline 13 & 138 & 554 & $\sqrt{56}$ & 57 & $\begin{array}{r}78 \\
\end{array}$ & 45 & 24 \\
\hline 11 & 39 & $\begin{array}{r}-4 \hat{\mathrm{V}} \\
\end{array}$ & 41 & 42 & 43 & 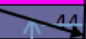 & $\Rightarrow$ \\
\hline 15 & 16 & 17 & 18 & 19 & 20 & 21 & 22 \\
\hline
\end{tabular}

Gambar 4 Pola Spiral dan Bajak Sawah

Dalam mencari nilai keacakan dengan menggunakan pola spiral dan bajak sawah diperlukan enam kali proses. Terlihat pada Gambar 4 dipisahkan menjadi empat bagian yaitu sisi kiri bawah, sisi kiri atas , sisi kanan bawah dan sisi kanan atas. Pengambilan dimulai dari pojok kiri bawah dengan pemakaian empat karakter (15) setelah itu keatas (38) dan turun kembali ke bawah dan naik kembali ke atas dengan mengikuti arah anak panah sehingga membentuk huruf $N$ dengan hasil menggunakan 16 karakter dalam satu sisi tersebut. Begitu juga untuk sisi kiri atas, sisi kanan bawah dan sisi kanan atas dilakukan dengan hal yang sama sehingga pengambilan membentuk huruf $N$ (28) dengan mengikuti arah anak panah yang ada.

Proses dengan pengujian enam kali putaran untuk mendapatkan nilai keacakan:

1. $\{15,14,39,16,13,12,37,38,17,40,41,18,55,54,63$, $56\}$

2. $\{11,10,35,36,9,8,7,34,53,52,51,62,33,6,5,32\}$

3. $\{19,42,43,20,57,64,59,58,21,44,23,22,45,46,25$, $24\}$

4. $\{61,50,49,60,31,1,3,30,47,48,27,26,29,2,1,28\}$ 


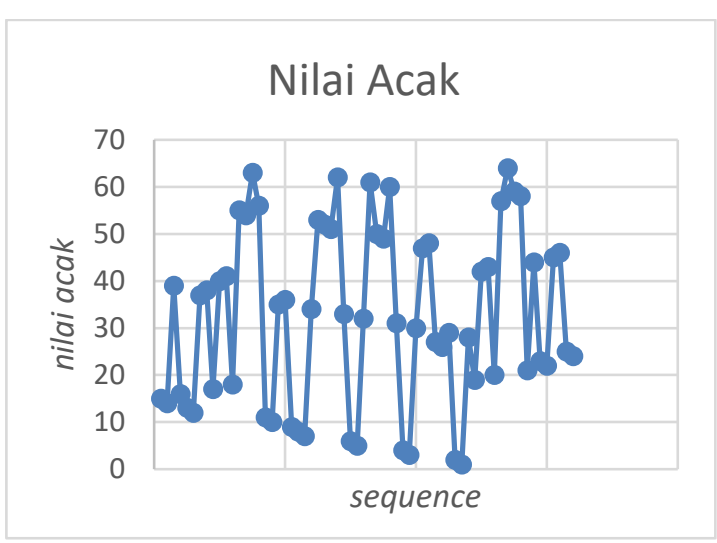

Gambar 5. Grafik Keacakan pada Pola Spiral dan Bajak Sawah

Dengan nilai-nilai keacakan tersebut membentuk grafik keacakan berasal dari pola pengambilan spiral dan pola pemasukan bajak sawah seperti pada Gambar 5.

TABEL I

HASIL PENGUJIAN PENGAMBILAN SPIRAL DAN PEMASUKAN BAJAK SAWAH

\begin{tabular}{|c|c|c|c|c|}
\hline Pengujian & Runtest & Monobit & Blockbit & Hasil \\
\hline Pengujian 1 & $\begin{array}{c}2.76369 \times \\
10^{-5}\end{array}$ & 1.00000000 & 1 & $\begin{array}{c}\text { Tidak } \\
\text { Acak }\end{array}$ \\
\hline Pengujian 2 & $\begin{array}{c}2.86459 \times \\
10^{-6}\end{array}$ & 1.00000000 & 0.99999933 & $\begin{array}{c}\text { Tidak } \\
\text { Acak }\end{array}$ \\
\hline Pengujian 3 & $\begin{array}{c}2.3257 \times 1 \\
0^{-7}\end{array}$ & 1.00000000 & 1 & $\begin{array}{c}\text { Tidak } \\
\text { Acak }\end{array}$ \\
\hline Pengujian 4 & $\begin{array}{c}2.3257 \times 1 \\
0^{-7}\end{array}$ & 1.00000000 & 1 & $\begin{array}{c}\text { Tidak } \\
\text { Acak }\end{array}$ \\
\hline Pengujian 5 & $\begin{array}{c}0.0012468 \\
8\end{array}$ & 1.00000000 & 1 & $\begin{array}{c}\text { Tidak } \\
\text { Acak }\end{array}$ \\
\hline Pengujian 6 & $\begin{array}{c}0.0218966 \\
15\end{array}$ & 1.00000000 & $\begin{array}{c}0.75640445 \\
1\end{array}$ & $\begin{array}{c}\text { Tidak } \\
\text { Acak }\end{array}$ \\
\hline
\end{tabular}

Tabel I adalah hasil dari enam kali percobaan pengujian untuk mendapatkan nilai keacakan dalam pola pengambilan spiral dan pola pemasukan bajak sawah dan mendapatkan nilai keacakan pada pengujian yang keenam dengan nilai runtest 0.021896615 , nilai monobit 1.0000000 dan nilai blockbit 0.756404451 .

Gambar 6 adalah hasil dari perhitungan untuk mencari nilai keacakan pada pola spiral dan bajak sawah.

\begin{tabular}{|c|c|}
\hline \multicolumn{2}{|c|}{ runtest } \\
\hline mean $=$ & 32,5 \\
\hline & \\
\hline $\mathrm{R}=$ & 25 \\
\hline $\mathrm{n} 0=$ & 32 \\
\hline $\mathrm{n} 1=$ & 32 \\
\hline $\mathrm{n}=$ & 64 \\
\hline $\mathrm{E}(\mathrm{R})=$ & 33,000 \\
\hline $\operatorname{Var}(\mathrm{R})=$ & 15,746 \\
\hline StDev $(\mathrm{R})=$ & 3,968 \\
\hline $\mathrm{Z}=$ & $-2,016$ \\
\hline $\mathrm{p}$-value $=$ & 0,02189662 \\
\hline$\alpha=$ & 0,01 \\
\hline \multicolumn{2}{|c}{} \\
\hline Hasil & ACAK \\
\hline
\end{tabular}

Gambar 6. Perhitungan Nilai Keacakan pada Pola Spiral dan Bajak Sawah

Hasil acak atau tidak acak didapatkan jika $p$-value kurang dari $\alpha$-value, maka hasilnya tidak acak, karena pada hasil ini didapatkan nilai $p$-value lebih besar dari nilai a-value maka menghasilkan nilai acak.

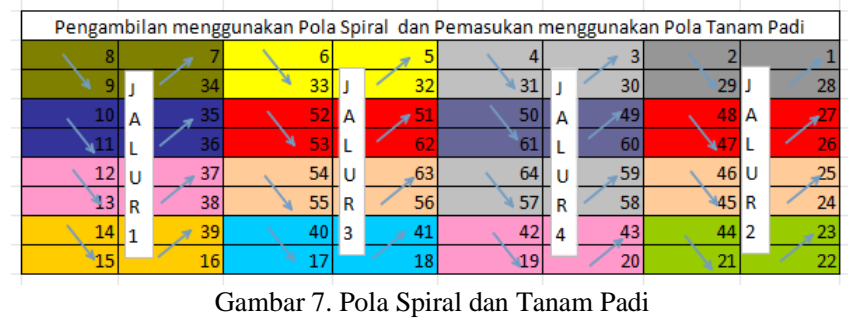

Dalam mencari nilai keacakan Gambar 7 dengan menggunakan pola pengambilan spiral dan pola pemasukan menggunakan tanam padi dibagi menjadi empat jalur yaitu jalur satu, jalur dua, jalur tiga dan jalur empat dimana jalur satu dan jalur tiga bersebelahan dissmping kiri sedangkan jalur dua dan jalur empat berada pada posisi samping kanan bersebelahan. Pengujian dimulai dari jalur satu samping kiri paling atas (8) dan mengikuti arah anak panah menurun ke bawah sampai akhir jalur satu (39). Selanjutnya pengujian pada jalur ke dua dengan pengambilan dimulai dari samping kanan bagian atas (2) mengukuti arah panah dan menuju ke arah bawah (23). Untuk jalur tiga dan jalur empat dilakukan pengujian seperti pada jalur satu dan jalur dua.

Proses dengan menggunakan pola pengambilan spiral dan pemasukan tanam padi terdapat tujuh kali pengujian mendapat nilai keacakan:

1. $\{8,9,7,34,10,11,36,35,12,13,37,38,14,15,39,16\}$

2. $\{2,29,28,1,48,47,26,27,46,45,24,25,44,21,22,23\}$

3. $\{6,33,32,5,52,53,62,51,54,55,56,63,40,17,18,41\}$

4. $\{4,31,30,3,50,61,60,49,64,57,58,59,42,19,20,43\}$ 


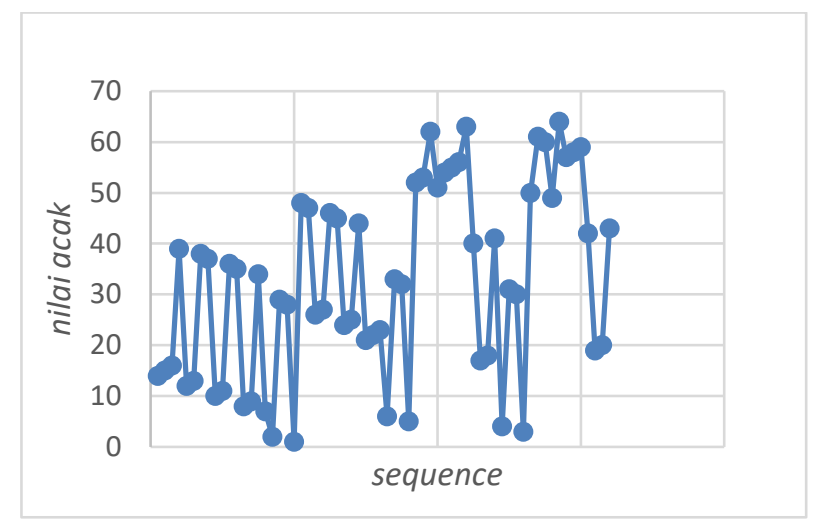

Gambar 8. Grafik Keacakan pada Pola Spiral dan Tanam Padi

Gambar 8 merupakan grafik keacakan nilai-nilai yang telah diuji dengan menggunakan pola pengambilan spiral dan pola pemasukan tanam padi.

TABEL II

HASIL PENGUJIAN PENGAMBILAN SPIRAL DAN PEMASUKAN TANAM PADI

\begin{tabular}{|c|c|c|c|c|}
\hline Pengujian & Runtest & Monobit & Blockbit & Hasil \\
\hline Pengujian 1 & $\begin{array}{c}0.0012468 \\
83\end{array}$ & 1.00000000 & 0.999707663 & $\begin{array}{c}\text { Tidak } \\
\text { Acak }\end{array}$ \\
\hline Pengujian 2 & $\begin{array}{c}2.3257 \times 10 \\
-7\end{array}$ & 1.00000000 & 1 & $\begin{array}{c}\text { Tidak } \\
\text { Acak }\end{array}$ \\
\hline Pengujian 3 & $\begin{array}{c}2.86459 \times 1 \\
0^{-6}\end{array}$ & 1.00000000 & 1 & $\begin{array}{c}\text { Tidak } \\
\text { Acak }\end{array}$ \\
\hline Pengujian 4 & $\begin{array}{c}0.0012468 \\
83\end{array}$ & 1.00000000 & 1 & $\begin{array}{c}\text { Tidak } \\
\text { Acak }\end{array}$ \\
\hline Pengujian 5 & $\begin{array}{c}0.0027848 \\
93\end{array}$ & 1.00000000 & 0.999970476 & $\begin{array}{c}\text { Tidak } \\
\text { Acak }\end{array}$ \\
\hline Pengujian 6 & $\begin{array}{c}0.0002092 \\
67\end{array}$ & 1.00000000 & 0.966491465 & $\begin{array}{c}\text { Tidak } \\
\text { Acak }\end{array}$ \\
\hline Pengujian 7 & $\begin{array}{c}0.0116623 \\
92\end{array}$ & 1.00000000 & 0.999904763 & Acak \\
\hline
\end{tabular}

Pada Tabel II adalah hasil dari tujuh kali proses percobaan untuk mencari nilai keacakan dengan menggunakan pola pengambilan spiral dan pola pemasukan tanam padi yang akhirnya pada pengujian ketujuh mendapatkan nilai acak dengan runtest 0.011662392 , nilai monobit 1.0000000 dan mendapatkan nilai blockbit 0.999904763 .

Gambar 9 adalah hasil dari perhitungan untuk mencari nilai keacakan pada pola spiral dan tanam padi.

\begin{tabular}{|c|c|}
\hline \multicolumn{2}{|c|}{ runtest } \\
\hline mean $=$ & 32,5 \\
\hline & \\
\hline $\mathrm{R}=$ & 24 \\
\hline $\mathrm{n} 0=$ & 32 \\
\hline $\mathrm{n} 1=$ & 32 \\
\hline $\mathrm{n}=$ & 64 \\
\hline $\mathrm{E}(\mathrm{R})=$ & 33,000 \\
\hline $\operatorname{Var}(\mathrm{R})=$ & 15,746 \\
\hline StDev $(\mathrm{R})=$ & 3,968 \\
\hline $\mathrm{Z}=$ & $-2,268$ \\
\hline $\mathrm{p}$-value $=$ & 0,011662392 \\
\hline$\alpha=$ & 0,01 \\
\hline \multicolumn{2}{|c}{} \\
\hline Hasil & ACAK \\
\hline \multicolumn{2}{|c}{}
\end{tabular}

Gambar 9. Perhitungan Nilai Keacakan pada Pola Spiral dan Tanam Padi

Hasil acak atau tidak acak didapatkan jika $p$-value kurang dari $\alpha$-value, maka hasilnya tidak acak, karena pada hasil ini didapatkan nilai $p$-value lebih besar dari nilai a-value maka menghasilkan nilai acak.

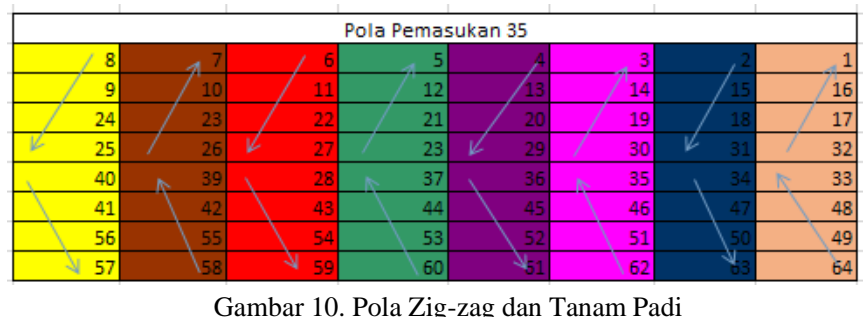

Pada Gambar 10 terdapat delapan sisi pada saat mencari nilai keacakan. Terdapat 35 kali percobaan untuk mencari nilai kecakan pada pola pengambilan zig-zag dan pola pemasukan tanam padi. Pencarian nilai keacakan dimulai dari mengambil angka paling kanan bawah (64) dengan melanjutkan ke atas sesuai arah anak panah sampai pada pojok kanan atas (1) dan kemudian lakukan juga kepada sisi ketujuh lainnya dengan arah naik-turun seperti arah anak panah dan berakhir pada kolom kiri bagian bawah (57).

Dalam pecarian nilai keacakan pada pola pengambilan zig-zag dan pola pemasukan tanam padi untuk pengujian monobit dan blockbit mendapatkan nilai yang acak sedangkan pengujian runtest tidak mendapatkan nilai yang acak sehingga harus dilakukan kembali pencarian nilai keacakan dengan menggunakan pola baru. 
TABEL III

HASIL PENGUJIAN PENGAMBILAN ZIG-ZAG DAN PEMASUKAN TANAM PADI

\begin{tabular}{|c|c|c|c|c|}
\hline Pengujian & Runtest & Monobit & $\begin{array}{c}\text { Block } \\
\text { Bit }\end{array}$ & Hasil \\
\hline Pengujian 1 & $\begin{array}{c}2.8088 \times \\
10^{-15}\end{array}$ & 1.00000000 & 1 & $\begin{array}{l}\text { Tidak } \\
\text { Acak }\end{array}$ \\
\hline Pengujian 2 & $\begin{array}{c}7.32395 \\
\times 10^{-10}\end{array}$ & 1.00000000 & 1 & $\begin{array}{l}\text { Tidak } \\
\text { Acak }\end{array}$ \\
\hline Pengujian 3 & $\begin{array}{c}2.8088 \times \\
10^{-15}\end{array}$ & 1.00000000 & 1 & $\begin{array}{l}\text { Tidak } \\
\text { Acak }\end{array}$ \\
\hline Pengujian 4 & $\begin{array}{c}1.48629 \\
\times 10^{-10}\end{array}$ & 1.00000000 & 1 & $\begin{array}{l}\text { Tidak } \\
\text { Acak }\end{array}$ \\
\hline Pengujian 5 & $\begin{array}{c}8.6082 \times \\
10^{-13}\end{array}$ & 1.00000000 & 1 & $\begin{array}{l}\text { Tidak } \\
\text { Acak }\end{array}$ \\
\hline Pengujian 6 & $\begin{array}{c}1.35338 \\
\times 10^{-13}\end{array}$ & 1.00000000 & 1 & $\begin{array}{l}\text { Tidak } \\
\text { Acak }\end{array}$ \\
\hline Pengujian 7 & $\begin{array}{c}1.48629 \\
\times 10^{-10} \\
\end{array}$ & 1.00000000 & 1 & $\begin{array}{l}\text { Tidak } \\
\text { Acak }\end{array}$ \\
\hline Pengujian 8 & $\begin{array}{c}1.3533 \times \\
10^{-13}\end{array}$ & 1.00000000 & 1 & $\begin{array}{l}\text { Tidak } \\
\text { Acak }\end{array}$ \\
\hline Pengujian 9 & $\begin{array}{c}5.11981 \\
\times 10^{-12}\end{array}$ & 0.72367361 & 1 & $\begin{array}{l}\text { Tidak } \\
\text { Acak }\end{array}$ \\
\hline Pengujian 10 & $\begin{array}{c}3.39201 \\
\times 10^{-9}\end{array}$ & 1.00000000 & 1 & $\begin{array}{l}\text { Tidak } \\
\text { Acak }\end{array}$ \\
\hline Pengujian 11 & $\begin{array}{c}2.83459 \\
\times 10^{-11}\end{array}$ & 1.00000000 & 1 & $\begin{array}{l}\text { Tidak } \\
\text { Acak }\end{array}$ \\
\hline Pengujian 12 & $\begin{array}{c}3.39201 \\
\times 10^{-9}\end{array}$ & 1.00000000 & 1 & $\begin{array}{l}\text { Tidak } \\
\text { Acak }\end{array}$ \\
\hline Pengujian 13 & $\begin{array}{c}7.32395 \\
\times 10^{-10}\end{array}$ & 1.00000000 & 1 & $\begin{array}{l}\text { Tidak } \\
\text { Acak }\end{array}$ \\
\hline Pengujian 14 & $\begin{array}{c}2.3257 \times \\
10^{-7}\end{array}$ & 1.00000000 & 1 & $\begin{array}{l}\text { Tidak } \\
\text { Acak }\end{array}$ \\
\hline Pengujian 15 & $\begin{array}{c}1.48629 \\
\times 10^{-10}\end{array}$ & 1.00000000 & 1 & $\begin{array}{l}\text { Tidak } \\
\text { Acak }\end{array}$ \\
\hline Pengujian 16 & $\begin{array}{c}1.48629 \\
\times 10^{-10}\end{array}$ & 1.00000000 & 1 & $\begin{array}{l}\text { Tidak } \\
\text { Acak }\end{array}$ \\
\hline Pengujian 17 & $\begin{array}{c}3.39201 \\
\times 10^{-9}\end{array}$ & 1.00000000 & 1 & $\begin{array}{l}\text { Tidak } \\
\text { Acak }\end{array}$ \\
\hline Pengujian 18 & $\begin{array}{c}2.3257 \times \\
10^{-7}\end{array}$ & 1.00000000 & 1 & $\begin{array}{l}\text { Tidak } \\
\text { Acak }\end{array}$ \\
\hline Pengujian 19 & $\begin{array}{c}2.8088 \times \\
10^{-15}\end{array}$ & 1.00000000 & 1 & $\begin{array}{l}\text { Tidak } \\
\text { Acak }\end{array}$ \\
\hline Pengujian 20 & $\begin{array}{c}3.39201 \\
\times 10^{-9}\end{array}$ & 1.00000000 & 1 & $\begin{array}{l}\text { Tidak } \\
\text { Acak }\end{array}$ \\
\hline Pengujian 21 & $\begin{array}{c}3.392 \times 1 \\
0^{-9}\end{array}$ & 1.00000000 & 1 & $\begin{array}{l}\text { Tidak } \\
\text { Acak }\end{array}$ \\
\hline Pengujian 22 & $\begin{array}{c}6.04369 \\
\times 10^{-8}\end{array}$ & 1.00000000 & 1 & $\begin{array}{l}\text { Tidak } \\
\text { Acak }\end{array}$ \\
\hline Pengujian 23 & $\begin{array}{c}1.4767 \times \\
10^{-8}\end{array}$ & 1.00000000 & 1 & $\begin{array}{l}\text { Tidak } \\
\text { Acak }\end{array}$ \\
\hline
\end{tabular}

Gambar 11. Perhitungan Nilai Keacakan pada Pola Zig-zag dan Tanam Padi

\begin{tabular}{|l|c|c|c|c|}
\hline Pengujian & Runtest & Monobit & $\begin{array}{c}\text { Block } \\
\text { Bit }\end{array}$ & Hasil \\
\hline Pengujian 24 & $\begin{array}{c}1.35338 \\
\times 10^{-13}\end{array}$ & 1.00000000 & 1 & $\begin{array}{c}\text { Tidak } \\
\text { Acak }\end{array}$ \\
\hline Pengujian 25 & $\begin{array}{c}1.48629 \\
\times 10^{-10}\end{array}$ & 1.00000000 & 1 & $\begin{array}{c}\text { Tidak } \\
\text { Acak }\end{array}$ \\
\hline Pengujian 26 & $\begin{array}{c}1.48629 \\
\times 10^{-10}\end{array}$ & 1.00000000 & 1 & $\begin{array}{c}\text { Tidak } \\
\text { Acak }\end{array}$ \\
\hline Pengujian 27 & $\begin{array}{c}2.83459 \\
\times 10^{-11}\end{array}$ & 1.00000000 & 1 & $\begin{array}{c}\text { Tidak } \\
\text { Acak }\end{array}$ \\
\hline Pengujian 28 & $\begin{array}{c}3.39201 \\
\times 10^{-9}\end{array}$ & 1.00000000 & 1 & $\begin{array}{c}\text { Tidak } \\
\text { Acak }\end{array}$ \\
\hline Pengujian 29 & $\begin{array}{c}1.35338 \\
\times 10^{-13}\end{array}$ & 1.00000000 & 1 & $\begin{array}{c}\text { Tidak } \\
\text { Acak }\end{array}$ \\
\hline Pengujian 30 & $\begin{array}{c}1.4767 \times \\
10^{-8}\end{array}$ & 1.00000000 & 1 & $\begin{array}{c}\text { Tidak } \\
\text { Acak }\end{array}$ \\
\hline Pengujian 31 & $\begin{array}{c}9.17249 \\
\times 10^{-6}\end{array}$ & 1.00000000 & 1 & $\begin{array}{c}\text { Tidak } \\
\text { Acak }\end{array}$ \\
\hline Pengujian 32 & $\begin{array}{c}2.8088 \times \\
10^{-15}\end{array}$ & 1.00000000 & 1 & $\begin{array}{c}\text { Tidak } \\
\text { Acak }\end{array}$ \\
\hline Pengujian 33 & $\begin{array}{c}6.04369 \\
\times 10^{-8}\end{array}$ & 1.00000000 & 1 & $\begin{array}{c}\text { Tidak } \\
\text { Acak }\end{array}$ \\
\hline Pengujian 34 & $\begin{array}{c}3.39201 \\
\times 10^{-9}\end{array}$ & 1.00000000 & 1 & $\begin{array}{c}\text { Tidak } \\
\text { Acak }\end{array}$ \\
\hline Pengujian 35 & $\begin{array}{c}7.32395 \\
\times 10^{-10}\end{array}$ & 1.00000000 & 1 & $\begin{array}{c}\text { Tidak } \\
\text { Acak }\end{array}$ \\
\hline
\end{tabular}

Dalam melakukan pengujian nilai keacakan pada Pola pengambilan zig-zag dan pola pemasukan tanam padi tidak mendapatkan nilai keacakan seperti pada Tabel III, maka dari itu dilakukannya percobaan dengan menggunakan pola baru yaitu pola motif batik bentenan dan pola pemasukan tanam padi.

Gambar 11 adalah hasil dari perhitungan untuk mencari nilai keacakan pada pola zig-zag dan tanam padi.

\begin{tabular}{|c|c|}
\hline \multicolumn{2}{|c|}{ runtest } \\
\hline mean $=$ & 32,5 \\
\hline & \\
\hline $\mathrm{R}=$ & 9 \\
\hline $\mathrm{n} 0=$ & 32 \\
\hline $\mathrm{n} 1=$ & 32 \\
\hline $\mathrm{n}=$ & 64 \\
\hline $\mathrm{E}(\mathrm{R})=$ & 33,000 \\
\hline $\operatorname{Var}(\mathrm{R})=$ & 15,746 \\
\hline $\mathrm{StDev}(\mathrm{R})=$ & 3,968 \\
\hline $\mathrm{Z}=$ & $-6,048$ \\
\hline $\mathrm{p}$-value $=$ & $7,3239 \mathrm{E}-10$ \\
\hline$\alpha=$ & 0,01 \\
\hline \multicolumn{2}{|}{} \\
\hline Hasil & TIDAK ACAK \\
\hline
\end{tabular}


Hasil acak atau tidak acak didapatkan jika $p$-value kurang dari $\alpha$-value, maka hasilnya tidak acak, karena pada hasil ini didapatkan nilai $a$-value lebih besar dari nilai $p$ value maka menghasilkan nilai tidak acak.
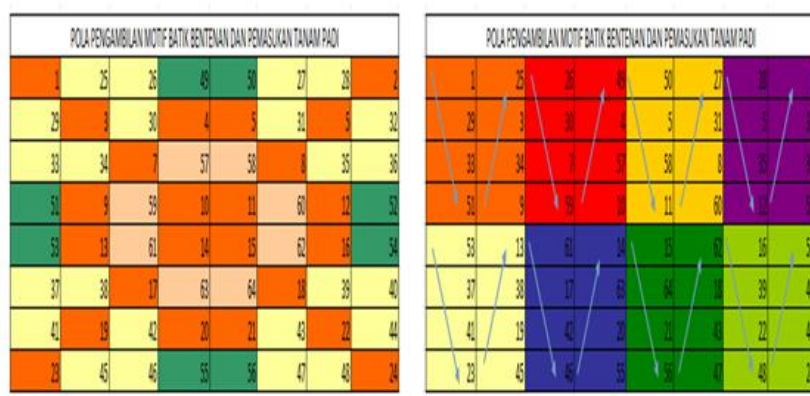

Gambar 12. Pola Motif Batik Bentenan dan Tanam Padi

Pada percobaan kali ini dengan menggunakan pola pemasukan baru motif batik bentenan dan pola pemasukan tanam padi sebagai salah satu pengujian untuk mendapatkan nilai keacakan. Gambar 12 memiliki dua gambar yaitu gambar disebelah kiri adalah pola motif batik bentenan sendiri dan gambar disebelah kanan adalah pencarian nilai keacakan dari pola tersebut. Pencarian nilai keacakan pada gambar sebelah kanan dibagi menjadi dua bagian yaitu bagian atas dan bagian bawah. Pengambilan awal dimulai dari bagian atas samping kiri (1) dan mengikuti arah anak panah dengan empat karakter berjejeran ke bawah atau ke atas sampai pada pojok kanan (2) dan untuk bagian bawah dilakukan hal yang sama seperti pada bagian yang diatas dari sebelah kiri bawah (53) sampai dengan bagian kanan bawah (54).

Proses pengambilan pola motif batik bentenan dan pemasukan tanam pagi hanya perlu dilakukan satu kali pengujian hingga mendapatkan nilai keacakan:

1. $\{1,29,33,51,9,34,3,25,26,30,7,59,10,57,4,49\}$

2. $\{50,5,58,11,60,8,31,27,28,5,35,12,52,36,32,2\}$

3. $\{53,37,41,23,45,19,38,13,61,17,42,46,55,20,63$, $14\}$

4. $\{15,64,21,56,47,43,18,62,16,39,22,48,24,44,40$, $54\}$

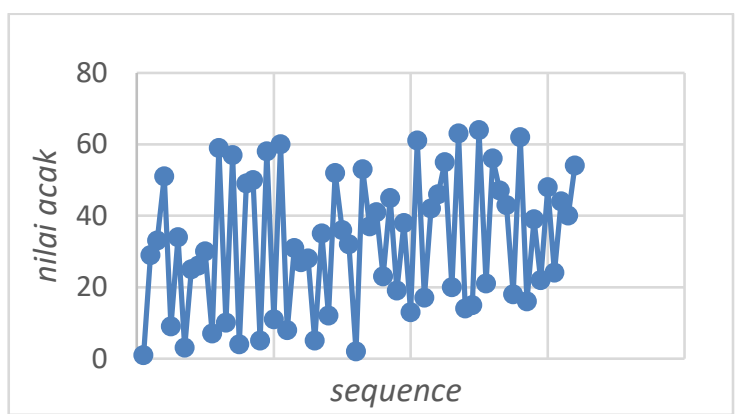

Gambar 13. Grafik Keacakan pada Pola Motif Batik Bentenan dan Tanam Padi

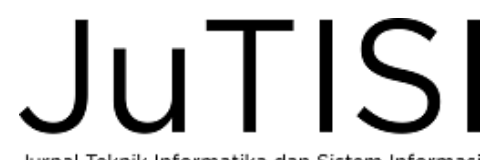

Jurnal Teknik Informatika dan Sistem Informasi
Gambar 13 merupakan grafik keacakan nilai-nilai yang telah diuji dengan menggunakan pola pengambilan pola motif batik bentenan dan pola pemasukan tanam padi.

TABEL IV

HASIL PENGUJIAN PENGAMBILAN MOTIF BATIK BENTENAN DAN PEMASUKAN TANAM PADI

\begin{tabular}{|c|c|c|c|c|}
\hline Pengujian & Runtest & Monobit & Blockbit & Hasil \\
\hline Pengujian 1 & $\begin{array}{c}0.988337 \\
608\end{array}$ & 1.00000000 & 0.999707663 & Acak \\
\hline
\end{tabular}

Tabel IV adalah hasil akhir dari pencarian nilai keacakan pada pola pengambilan motif batik bentenan dan pola pemasukan tanam padi dengan nilai runtest 0.988337608 , nilai monobdit 1.00000000 dan mendapatkan nilai blockbit 0.999707663

Pada pencarian nilai keacakan dengan menguji pola pengambilan zig-zag dan pola pemasukan tanam padi mendapatkan hasil tidak acak dikarenakan pemasukan angka dengan alur zig-zag bersifat berurutan sehingga pada saat dilakukannya pengujian dengan pola tanam padi secara vertikal maupun horizontal tidak bisa mendapatkan nilai keacakan. Sedangkan dengan pengujian menggunakan pola pengambilan motif batik bentenan dan pola pemasukan tanam padi mendapatkan nilai acak dikarenakan pemasukan angka pada pola motif batik bentenan tersebut tidak berurutan sehingga pada saat pengujian dengan pola tanam padi secara vertikal maupun horizontal mendapatkan nilai acak sehingga pengujian nilai keacakan terpenuhi.

Gambar 14 adalah hasil dari perhitungan untuk mencari nilai keacakan pada pola motif Batik Bentenan dan tanam padi.

\begin{tabular}{|c|c|}
\hline \multicolumn{2}{|c|}{ runtest } \\
\hline mean $=$ & 32,484375 \\
\hline & \\
\hline$R=$ & 42 \\
\hline$n 0=$ & 32 \\
\hline$n 1=$ & 32 \\
\hline$n=$ & 64 \\
\hline$E(R)=$ & 33,000 \\
\hline $\operatorname{Var}(R)=$ & 15,746 \\
\hline StDev( $R)=$ & 3,968 \\
\hline$Z=$ & 2,268 \\
\hline$p$-value $=$ & 0,988337608 \\
\hline$\alpha=$ & 0,01 \\
\hline \multicolumn{2}{|c}{} \\
\hline Hasil & ACAK \\
\hline
\end{tabular}

Gambar 14. Perhitungan Nilai Keacakan pada Pola Motif Batik Bentenan dan Tanam Padi

Hasil acak atau tidak acak didapatkan jika $p$-value kurang dari $\alpha$-value, maka hasilnya tidak acak, karena pada hasil ini didapatkan nilai $p$-value lebih besar dari nilai $a$-value maka menghasilkan nilai acak. 
TABEL $\mathrm{V}$

HASIL PENELITIAN POLA PENGAMBILAN DAN PEMASUKAN SEBELUM MODIFIKASI

\begin{tabular}{|c|c|c|c|c|c|}
\hline \multirow{2}{*}{ No } & \multirow{2}{*}{$\begin{array}{c}\text { Pengambilan } \\
\text { dan Pemasukan }\end{array}$} & \multicolumn{3}{|c|}{$p$-value } & \multirow{2}{*}{ Hasil } \\
\hline & & Run Test & Mono Bit & $\begin{array}{c}\text { Block } \\
\text { Bit }\end{array}$ & \\
\hline 1. & $\begin{array}{l}\text { Pola } \\
\text { Pengambilan } \\
\text { Spiral \& } \\
\text { Pemasukan } \\
\text { Bajak Sawah }\end{array}$ & $\begin{array}{c}2.76369 \times \\
10^{-5}\end{array}$ & $\begin{array}{c}1.0000000 \\
0\end{array}$ & 1 & $\begin{array}{l}\text { Tidak } \\
\text { Acak }\end{array}$ \\
\hline 2. & $\begin{array}{l}\text { Pola } \\
\text { Pengambilan } \\
\text { Spiral \& } \\
\text { Pemasukan } \\
\text { Tanam Padi }\end{array}$ & 0.012469 & $\begin{array}{c}1.0000000 \\
0\end{array}$ & $\begin{array}{c}0.999 \\
70766 \\
3\end{array}$ & $\begin{array}{l}\text { Tidak } \\
\text { Acak }\end{array}$ \\
\hline 3. & $\begin{array}{l}\text { Pola } \\
\text { Pengambilan } \\
\text { Spiral \& } \\
\text { Pemasukan } \\
\text { Tanam Padi }\end{array}$ & $\underset{-15}{2.8088 \times 10}$ & $\begin{array}{c}1.0000000 \\
0\end{array}$ & 1 & $\begin{array}{l}\text { Tidak } \\
\text { Acak }\end{array}$ \\
\hline
\end{tabular}

Tabel V dalah hasil dari setiap penelitian awal yang belum dimodifikasi polanya, sehingga mendapatkan nilai yang tidak acak dalam pengujian runtest, monobit dan blockbit.

TABEL VI

HASIL PENELITIAN POLA PENGAMBILAN DAN PEMASUKAN SETELAH MODIFIKASI

\begin{tabular}{|c|c|c|c|c|c|}
\hline \multirow{2}{*}{ No } & \multirow{2}{*}{$\begin{array}{l}\text { Pengambilan } \\
\text { dan } \\
\text { Pemasukan }\end{array}$} & \multicolumn{3}{|c|}{ p-value } & \multirow{2}{*}{ Hasil } \\
\hline & & Run Test & Mono Bit & $\begin{array}{c}\text { Block } \\
\text { Bit }\end{array}$ & \\
\hline 1. & $\begin{array}{l}\text { Pola } \\
\text { Pengambilan } \\
\text { Spiral \& } \\
\text { Pemasukan } \\
\text { Bajak Sawah }\end{array}$ & $\begin{array}{c}0.021896 \\
615\end{array}$ & $\begin{array}{c}1.000000 \\
00\end{array}$ & $\begin{array}{c}0.7564 \\
04451\end{array}$ & Acak \\
\hline 2. & $\begin{array}{l}\text { Pola } \\
\text { Pengambilan } \\
\text { Spiral \& } \\
\text { Pemasukan } \\
\text { Tanam Padi }\end{array}$ & $\begin{array}{c}0.011662 \\
392\end{array}$ & $\begin{array}{c}1.000000 \\
00\end{array}$ & $\begin{array}{c}0.9999 \\
0476\end{array}$ & Acak \\
\hline 3. & $\begin{array}{l}\text { Pola } \\
\text { Pengambilan } \\
\text { Zig-zag \& } \\
\text { Pemasukan } \\
\text { Tanam Padi }\end{array}$ & $\begin{array}{c}7.32395 \times \\
10^{-10}\end{array}$ & $\begin{array}{c}1.000000 \\
00\end{array}$ & 1 & $\begin{array}{l}\text { Tidak } \\
\text { Acak }\end{array}$ \\
\hline 4. & $\begin{array}{l}\text { Pola } \\
\text { Pemasukan } \\
\text { Motif Batik } \\
\text { Bentenan dan } \\
\text { Pengambilan } \\
\text { Tanam Padi } \\
\end{array}$ & $\begin{array}{c}0.988337 \\
608\end{array}$ & $\begin{array}{c}1.000000 \\
00\end{array}$ & $\begin{array}{r}0.9997 \\
07663\end{array}$ & Acak \\
\hline
\end{tabular}

Tabel VI adalah hasil dari setiap penelitian yang sudah diuji kembali dengan pola pengambilan dengan pola pemasukan. Berdasarkan dari empat data yang sudah diperoleh maka nilai $p$-value terbesar adalah runtest $7.3239 \times 10^{-10}$ dengan nilai $p$-value monobit 1.00000000 dan nilai $p$-value blockbit 1 sehingga mendapatkan hasil tidak acak dan nilai $p$-value terkecil yaitu 0.011662392 dengan nilai $p$-value monobit 1.00000000 dan nilai $p$-value blockbit adalah 0.99990476 sehingga pengujian ini mendapatkan hasil acak.

\section{SIMPULAN}

Berdasarkan perancangan yang telah dibuat dapat disimpulkan bahwa Modifikasi Skema Teknik Tanam Padi dan Bajak Sawah Berbasis Square Transposition 64-bit sebagai Pemdenuhan Nilai Keacakan dapat dikatakan acak apabila pengujian tersebut tidak bersifat berurutan pada saat dimasukan kedalam square transposition 64-bit berukuran 8x8. Maka dari itu pola pengambilan zig-zag tidak disarankan untuk dipakai pada saat akan mencari nilai keacakan dikarenakan akan mendapatkan hasil tidak acak.

Dari hasil perbandigan setiap pengujian menggunakan pola pengambilan dan pola pemasukan didapatkan nilai $p$ value terbesar adalah runtest $7.32395 \times 10^{-10}$ dengan nilai $p$ value monobit 1.00000000 dan nilai p-value blockbit 1 sehingga mendapatkan hasil tidak acak dan nilai $p$-value terkecil yaitu 0.011662392 dengan nilai $p$-value monobit 1.00000000 dan nilai $p$-value blockbit adalah 0.99990476 sehingga pengujian ini mendapatkan hasil acak.

\section{UCAPAN TERIMA KASIH}

Terima kasih saya ucapkan kepada Pembimbing saya Ibu. Magdalena A. Ineke Pakereng yang dan Reviewer saya Bapak Alz D. Wowor yang sudah membantu dan membimbing saya sehingga penelitian ini bisa selesai.

\section{DAFTAR PUSTAKA}

[1] A. Widodo, A. D. Wowor, E. Mailoa, and M. A. I. Pakereng, "Perancangan Kriptografi Block Cipher Berbasis pada Teknik Tanam Padi dan Bajak Sawah," Salatiga, pp. 2-7, 2015

[2] Bruce Schneier,Applied Cryptography,Protocols,Algorithms \& Source Code in C, 20th Anniversary Edition, 2015, Wiley, page 45.

[3] N. D. Nathasia and A. E. Wicaksono, "Penerapan Teknik Kriptografi Stream-Cipher Untuk Pengaman Basis Data," ICT Research Center UNAS, Jurnal Basis Data, Jakarta Selatan, vol. 6, 2011.

[4] A. D. Wowor, M. A. I. Pakereng, F. Tuhumury, and A. D. Wowor, "Perancangan Kriptografi Block Cipher 256 Bit Berbasis pada Pola Tuangan Air." Jurusan Teknik Informatika Universitas Kristen Satya Wacana, Salatiga, 2016.

[5] I. M. M. K. Astawa, "Strategi Penerapan Uji Keacakan Barisan Bit Menggunakan Uji Run,” vol. 1, no. 1, 2014.

[6] A. Rukhin, J. Soto, and J. Nechvatal, "A Statistical Test Suite for Random and Pseudorandom Number Generators for Cryptographic Applications, ”'April, 2010.

[7] D. Sinaga and C. Umam, "Implementasi kriptografi vigenere cipher pada media teks dengan kombinasi transposisi kolom 1,2," Pros. SENDI_U 2018 ISBN 978-979-3649-99-3, no. 1, pp. 978-979, 2018 . 
[8] M. A. I. Pekereng and A. D. Wowor, "Square Transposition : Suatu Pendekatan Proses Transposisi dalam Block Cipher," vol. x, no. x, pp. 1-8, 2018, doi: 10.11591/eei.vxix.yyyy.

[9] A. P. Tololiu, "Perlindungan Hukum Terhadap Kain Bentenan Sebagai Ekspresi Budaya Tradisional Sulawesi Utara,” vol. 2, no. 2, pp. 1-12, 2014.

[10] A. F. Lowis, A. P. K, R. P. Sutanto, and J. Siwalankerto, "Perancangan Fotografi Esai Tentang Peran Masyarakat Manado dalam Mengapresiasi Kain Tenun Bentenan,” vol. 1, no. 14, 2019.

[11] D. P. S. Hum, B. Agus, S. S. Iip, and A. P. Manangkalangi, "Perancangan Typeface Latin Hasil Adaptasi Budaya Suku Minahasa," Fti Umn, vol. 53, no. 9, pp. 1-15, 2018.

[12] S. H. Yonatan, H. D. Purnomo, and A. D. Wowor, "Perancangan Kriptografi Block Cipher Berbasis pada Garis Pertumbuhan dan Pita Pertumbuhan Cangkang Kerang," Salatiga, 2015. [Online]. Tersedia: https://repository.uksw.edu/handle/123456789/15079. 